\title{
NPK Levels and Application Methods on Productivity of Amorphophallus muelleri Blume in Intercropping System
}

Penulis

Afiliasi

\section{Edi Santosa $^{1}{ }^{*}$, Anas Dinurrohman Susila ${ }^{1}$, Adolf Pieter Lontoh ${ }^{1}$, Yoko Mine ${ }^{2}$ and Nobuo} Sugiyama $^{2}$

\footnotetext{
${ }^{1}$ Faculty of Agriculture, Bogor Agricultural University. Bogor 16168 Indonesia.

${ }^{2}$ Faculty of Agriculture, Tokyo University of Agriculture, Funako, Atsugi, Kanagawa 243-0034, Japan
}

\section{Kata Kunci \\ P Fertilizer \\ $\partial$ lles-iles \\ Intercropping \\ $\rightarrow$ Production \\ $\rightarrow$ tuber crop}

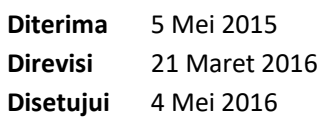

*Penulis korespondensi Edi Santosa Faculty of Agriculture, Bogor Agricultural University. Bogor 16168 Indonesia Tel. +62-251-8629353 edisang@gmail

\section{Abstract}

Underground corm of Amorphophallus muelleri Blume contained glucomannan, a raw material widely used in beverage, food and medicinal industries. In Indonesia, A. muelleri is grown under intercropping system, however, average corm production was considered low. The low productivity could be related to the low input of chemical fertilizers. Therefore, the effects of NPK fertilizers and methods of application on A. muelleri productivity were evaluated in the present study for intercropping system. Two experiments were conducted at Leuwikopo Experimental Farm, Bogor, Indonesia from 2010-2012 under canopy of coffee trees. First experiment was conducted using four levels of $\mathrm{N}, \mathrm{P}$, and $\mathrm{K}$ applications, i.e., $\mathrm{N}: \mathrm{P}_{2} \mathrm{O}_{5}: \mathrm{K}_{2} \mathrm{O}$ at the rate 0:0:0, 100:60:80, 125:60:100 and 150:60:120 kg ha ${ }^{-1}$. In second experiment, $\mathrm{N}: \mathrm{P}_{2} \mathrm{O}_{5}: \mathrm{K}_{2} \mathrm{O}$ fertilizers at the rate of 100:60:80 were applied by conventional (solid) and liquefied. Results of first experiment showed that application of N, P and $\mathrm{K}$ at rate of $100 \mathrm{~kg}, 60 \mathrm{~kg}$, and $80 \mathrm{~kg} \mathrm{ha}^{-1}$ produced fresh corm weight $636.3 \pm 91.7 \mathrm{~g}$ per plant or increased by $63 \%$ higher than control. However, higher rate of NPK application did not increase corm yield, possibly due to the occurrence of leaf discoloration. Higher rates of NPK also delayed harvest time 1 to 2 weeks compared with control and caused wide variation of corm size. Thus, excess application of NPK should be avoided for high productivity of $A$. muelleri. Second experiment showed that there was no significant different among methods of application on fresh corm weight, i.e., $413 \mathrm{~g}$ and $396 \mathrm{~g}$ from conventional and liquefied applications, respectively. These experiments conclude that application of NPK is important to enhance $A$. muelleri production in intercropping system.

\section{Introduction}

lles-iles (Amorphophallus muelleri Blume.) is has been introduced as new cash crop in intercropping system in Indonesia (Santosa and Sugiyama 2008). The corm contains glucomannan, a kind of low digestive carbohydrate, from 55\% (Ohtsuki 1968) to $72 \%$ on dry basis (Zhang et al. 2010). Annual world production of mannan flour is 30,000 tons (Liu 2004). Potentially, one $\mathrm{kg}$ of mannan flour and 0.6-1.0 kg of starch can be extracted from about $14 \mathrm{~kg}$ of fresh $A$. muelleri corms 
Glucomannan is widely used in industries of low caloric food and beverages, medicines, and chemicals (Jansen et al. 1996; Fang \& Wu 2004; Sugiyama \& Santosa, 2008). Alonso-Sande et al. (2009) stated, glucomannan is a very promising polysaccharide incorporated into the drug to decrease the serum glucose levels of diabetes type 2, inhibit growth of sarcoma tumor, ideal as tablets filler and nanocarriers of drug to specific receptors; and since 2005 more than 700 publications annually were recorded worldwide on biomedical and pharmaceutical aspects.

In Indonesia, commercial areas of $A$. muelleri are estimated 10,000 hectares are spreading over Java, Sulawesi, Bali and Flores islands. Each year, about 300 tons of dried corms are exported to China, Korea and Japan (Harlan-exporter in Jakarta, personal communication). They are cultivated under nonintensive intercropping system, thus productivity is low. Under teak agroforestry in East Java, productivity of $A$. muelleri was 6-10 tons fresh tuber $\mathrm{ha}^{-1}$ year $^{-1}$, although Santosa et al. (2003) estimated that potential yield was 40 tons ha $^{-1}$ year $^{-1}$. The low productivity of $A$. muelleri in agroforestry is possibly due to low agronomic management, particularly low fertilizer application.

Fertilizer application, especially potassium is an important nutrient to increase tuber yield, quality and carbohydrate content in tuber crops (Singh et al. 1993; Das et al. 2003). Ashokan \& Nair (1984) stated that K removal from taro field is much higher than that of $\mathrm{N}$. However, the effects of NK and PK fertilizers application were often non consistence (Santosa et al. 2011; Sumarwoto \& Widodo 2008). Sumarwoto \& Widodo (2008) recommend applying 7.5 tons $\mathrm{ha}^{-1}$ of organic manure and 4 ton ha ${ }^{-1}$ of chalk in addition of
NK for $A$. muelleri growing. It is probable that balanced and method of application of NPK is necessary to attain maximum growth. Therefore, the objectives of the experiments were to study the effect of NPK levels and application methods on productivity of $A$. muelleri in intercropping system.

\section{Materials and Methods}

Two consecutive field experiments were conducted at under canopy of coffee tree (Coffea robusta) plantation at the Leuwikopo Experimental Farm of Bogor Agricultural University, Darmaga (260 m above sea level), during rainy season August 2010 to July 2012. The original soil (Latosol Darmaga soil) had $\mathrm{pH} 5.2$, contained low amount of total nitrogen $(0.12 \%$ by Kjeldhl method), phosphorus (5.9 ppm by Bray I method) and exchangeable potassium ( 0.26 me $100 \mathrm{~g}$ $\left.{ }^{1}\right)$. Soil texture was sand $13.13 \%$, silt $22.06 \%$ and clay $64.79 \%$.

Coffee tree plantation was established in 1994 from seedlings at distance of $6 \mathrm{~m} \times 2 \mathrm{~m}$. Plots of $4 \mathrm{~m} \times 6$ $m$ were made between coffee tree rows (Fig. 1A). Coffee tree canopy was maintained at a height of $4 \mathrm{~m}$ and at a width of $4.5 \mathrm{~m}$ on average. Light intensity near coffee trees about $40 \%$ and at middle row among coffee trees was 90 to $100 \%$, with average light intensity was reduced by $65 \%$ of that from open area. Day temperature during the experiment ranged from 23 to $32{ }^{\circ} \mathrm{C}\left(26{ }^{\circ} \mathrm{C}\right.$ on average) with average air relative humidity $87 \%$.

\section{First Experiment}

Soil was plowed and harrowed using tractor at a depth of $30 \mathrm{~cm}$ two months prior to planting. Planting beds seized $20 \mathrm{~cm}$ height and $100 \mathrm{~cm}$ width were

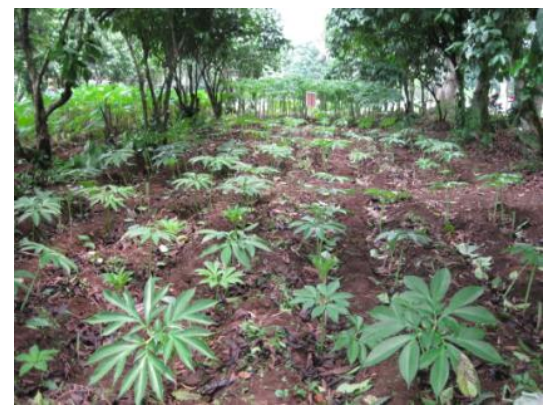

(A)

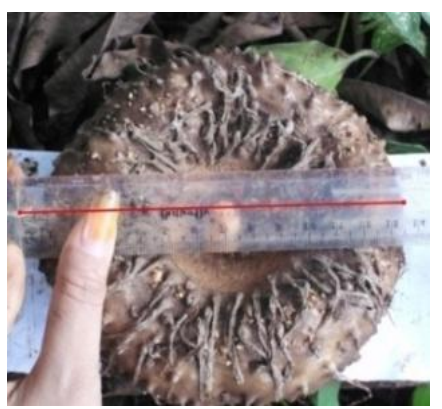

(B)

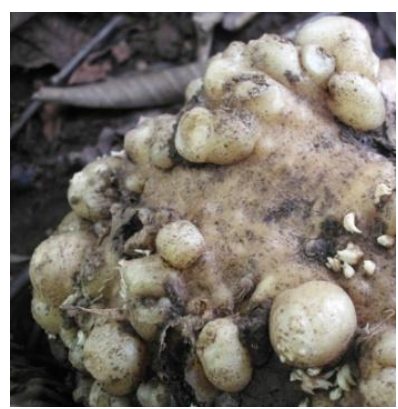

(C)

Fig 1. Intercropping $A$. muelleri with coffee trees in Bogor, Indonesia (Exp. I), at 8 weeks after planting (A). Healthy corm of $A$. muelleri and method of corm diameter measurement (B), infected corm by nematodes showed ballon-like form on the corm skin (C). 
raised after harrowing. One ton of $\mathrm{CaCO}_{3}$ powder was spread over the planting beds. Four weeks prior to planting, rice husk was spread $3-5 \mathrm{~cm}$ thickness in the planting hole, and two weeks prior to planting, goat manure (air dried) was applied at the rate of 10 ton ha 1.

One-year-old corms (harvested from seedling of small bulbils) with about $1.0 \mathrm{~cm}$ bud in height were planted at a distance $60 \mathrm{~cm} \times 80 \mathrm{~cm}$ in rainy season (August 8, 2010). Average seed corm weight was $49 \pm 26$ g with diameter $3.6 \pm 0.7 \mathrm{~cm}$. Corms were buried $5 \mathrm{~cm}$ below soil surface with bud face up. The bed was arranged in completely randomized complete block design with three replicates. In each replication, 50 corms were planted in each and 10 plants were randomly observed. At planting, about two gram Furadan $3 G{ }^{\circledR}$ was applied on cavity of bud.

Four combinations of nitrogen, phosphorus and potassium (NPK) were applied, i.e., 0:0:0, 100:60:80, 125:60:100 and 150:60:120 kg ha- Nitrogen was provided from urea $(46 \% \mathrm{~N})$, phosphorus from SP$36\left(36 \% \mathrm{P}_{2} \mathrm{O}_{5}\right)$, and potassium from $\mathrm{KCl}\left(60 \% \mathrm{~K}_{2} \mathrm{O}\right)$. The amounts of $\mathrm{K}$ fertilizer were determined according to Jansen et al. (1996) for A. paeoniifolius, and amounts of nitrogen and phosphorus according to Sumarwoto and Widodo (2008) and Wilson and Siemonsma (1996). NPK fertilizers were applied twice. First application was four weeks after planting (WAP) at which time bud elongation reached about $20 \mathrm{~cm}$ from soil surface. Second application was at 4 weeks after the fully expansion of the first leaf (8 WAP).

Soil was regularly raised every month. Supplemented watering was applied, if rainfall was less than $20 \mathrm{~mm}$ day $^{-1}$ each for three consecutive days. Hand weeding was carried out twice a month. Pesticides Furadan $3 G{ }^{\circledR}$, Basudin 15 EC ${ }^{\circledR}$ and Dithane M45 ${ }^{\circledR}$ for pest and diseases control were applied monthly. Plant growth, i.e., number of leaves, leaf size and time to dormancy was observed. Petiole height was measured from $3 \mathrm{~cm}$ above soil level to the branch of tripartite rachis. Canopy size was determined by measuring the horizontal distance between the tips of a tripartite leaf and petiole. Correlation between plant size and yield has been well documented (Santosa et al. 2003; Sugiyama \& Santosa 2008). Leaf number was calculated based on order of it emergence, the first leaf emerged earlier than the second. Plant height measured from soil level to tripartite rachis. Petiole diameter was measured at $5 \mathrm{~cm}$ above soil level. Bulbil size larger than $0.5 \mathrm{~cm}$ in diameter was considered.

Daughter corm size and weight were measured at harvest. Harvest was carried out in March 18, 2011 after dormancy. Dormancy was judged by the complete senescence of leaves. Dry matter content was measured after oven drying of peeled corm at the $120^{\circ} \mathrm{C}$ for 3 days. Statistical evaluation was conducted using $\mathrm{F}$ test, and for significant data was analyzed further with Duncan Multiple Range Test (DMRT).

\section{Second experiment}

Experiment was conducted in June 2011 to February 2012 in the same location with experiment I. Average relative humidity was $80-85 \%$, light intensity under the coffee canopy was $50-90 \%$ and temperature 26.1-30.5 ${ }^{\circ} \mathrm{C}$. One-year-old corms of $A$. muelleri were planted in June 22, 2011 at distance $80 \mathrm{~cm}$ by $50 \mathrm{~cm}$ supplemented with 5 ton of organic manure applied two weeks prior to planting.

Randomized complete block design were applied in this experiment, with tree replicates. In each replication 16 plants were maintained and 5 plants were selected randomly for measurement. Two method of fertilizer applications were evaluated, i.e., conventional (broadcasting) and liquefied. In conventional application, solid NPK fertilizers were broadcasted directly surrounding crop petiole, while in liquefied application, the NPK fertilizers were diluted in water and applied manually by using plastic cup as in fertigation. Plants without any NPK fertilizers were evaluated as control.

Nitrogen (N), Phosphorus (P) and potassium (K) fertilizers from Urea $(46 \% \mathrm{~N}), \mathrm{SP}-36\left(36 \% \mathrm{P}_{2} \mathrm{O}_{5}\right)$, and $\mathrm{KCl}$ $\left(60 \% \mathrm{~K}_{2} \mathrm{O}\right)$ at rate 100:60:80 $\mathrm{kg} \mathrm{ha}^{-1}$, respectively, were applied. Half of $\mathrm{N}, \mathrm{P}$ and $\mathrm{K}$ doses was applied at one month after leaf emergence ( 3 months after plantingMAP; September 14, 2011) while the rest were applied after first leaf fully expanded (4 MAP; October 12, 2011). Crop maintenances such as weeding, irrigating, and pest controlling followed as in Exp. I. Harvesting was conducted at 36 MAP (February 29, 2012) after $80 \%$ of crops dormant. Crop evaluation and data analysis followed Exp. I.

\section{Results and Discussion \\ First Experiment}

Leaf Size and Number. NPK applications increased leaf size, but did not increase number of 
leaflets (Table 1). Percentage of plant produced two leaves was significantly high at 100:60:80 NPK than other three treatments. Field observation showed that leaf discoloration occurred more often in high NPK treatments. Leaf discoloration might be caused by strong intensity of sunshine. In intercropping, light intensity close to coffee trees was low, but it became high at the center during day time (Fig.1A). Santosa et al. (2006) reported that $A$. muelleri exhibited high productivity at $50 \%$ or less light intensity of full sunshine.

High NK treatments, i.e., 125:60:100 and 150:60:120 kg ha ${ }^{-1}$, tended to increase plant height, petiole diameter and number of bulbils of the first leaf. Second leaf size was significantly higher in NPK treatments than in control. This finding is in line with results of Santosa et al. (2011), that application of $\mathrm{N}$ and $\mathrm{K}$ fertilizers significantly increased the number of leaves, the number of leaflets and second leaf size.

Table 1 shows that there were no significant differences in leaf size among NPK levels. It is likely that NPK treatment was more effective to increase leaf size for the second leaf than for the first leaf. Application of NPK at level of 100:60:80 kg ha ${ }^{-1}$ and 150:60:120 kg ha ${ }^{-1}$ tended to had higher leaf size of the second leaf than of 125:60:100 kg ha-1. In plants treated with NPK 150:60:120 kg ha-1 produced lower number of leaf as compared to $100: 60: 80 \mathrm{~kg} \mathrm{ha}^{-1}$ (Fig. 2). It is important to note that from NPK 150:60:120 kg ha ${ }^{-1}$, two replications had $100 \%$ of plants with two leaves, but absent of all plants in one replication. It is likely that inconsistent effect of NPK 150:60:120 kg ha-1 treatment as compared to $100: 60: 80 \mathrm{~kg} \mathrm{ha}^{-1}$, probably due to physiological problem so that available second leaf buds failed to expand.

Corm weight. Application of NPK at level of 100:60:80 kg ha ${ }^{-1}$ significantly increased corm weight (Table 2). However, there were no significant differences in corm weight among high NK treatments and control. Furthermore, corm diameter and height were larger in NPK treatment at level of 100:60:80 kg $\mathrm{ha}^{-1}$ than others. NPK treatments increased corm dry matter content in $A$. muelleri than control treatment. Judging glucomannan content ca $55 \%$ of dry mass (Sugiyama \& Santosa 2008), NPK application produced more glucomannan than control.

In the highest NK treatment, i.e., 150:60:120 kg $\mathrm{ha}^{-1}$, the percentage of healthy corms was higher than in other treatments (Table 3). Healthy corm was determined as corms free of disease and with acceptable shape to market. However, highest NK treatments caused high variation on corm size, ranging from $50 \mathrm{~g}$ to larger than $1,000 \mathrm{~g}$ (Table 3 and Table 4). Table 3 shows that application of NPK delayed harvest

Table 1. Leaf size of $A$. muelleri plants from different NPK application grown under intercropping with coffee tree from experiment in 2010 to 2011

\begin{tabular}{|c|c|c|c|c|c|c|c|c|c|c|}
\hline \multirow[b]{2}{*}{$\begin{array}{c}\text { NPK } \\
\text { Combination }\end{array}$} & \multicolumn{5}{|c|}{ First leaf } & \multicolumn{5}{|c|}{ Second leaf } \\
\hline & $\begin{array}{l}\text { Height } \\
(\mathrm{cm})\end{array}$ & $\begin{array}{c}\text { No. } \\
\text { Leaflet }\end{array}$ & $\begin{array}{c}\varnothing \text { Petiole } \\
(\mathrm{cm})\end{array}$ & $\begin{array}{c}\text { No. } \\
\text { bulbil }\end{array}$ & $\begin{array}{c}\text { Canopy } \\
\text { area }\left(\mathrm{m}^{2}\right)\end{array}$ & $\begin{array}{l}\text { Height } \\
(\mathrm{cm})\end{array}$ & $\begin{array}{c}\text { No. } \\
\text { Leaflet }\end{array}$ & $\begin{array}{c}\varnothing \text { Petiole } \\
(\mathrm{cm})\end{array}$ & $\begin{array}{c}\text { No. } \\
\text { bulbil }\end{array}$ & $\begin{array}{c}\text { Canopy } \\
\text { area }\left(\mathrm{m}^{2}\right)\end{array}$ \\
\hline No NPK & $51.5 \pm 0.7$ & $22.0 \pm 0.5$ & $1.5 \pm 0.0$ & $1.1 \pm 0.1$ & $0.39 \pm 0.01$ & $81.7 \pm 0.4$ & $31.0 \pm 1.4$ & $2.3 \pm 0.0$ & $3.4 \pm 0.4$ & $0.69 \pm 0.04$ \\
\hline 100:60:80 & $50.7 \pm 0.4$ & $23.3 \pm 0.6$ & $1.5 \pm 0.0$ & $1.3 \pm 0.2$ & $0.38 \pm 0.01$ & $86.1 \pm 1.8$ & $34.8 \pm 1.8$ & $2.6 \pm 0.0$ & $3.9 \pm 0.2$ & $0.75 \pm 0.03$ \\
\hline 125:60:100 & $54.3 \pm 1.0$ & $26.3 \pm 1.6$ & $1.6 \pm 0.0$ & $1.9 \pm 0.2$ & $0.38 \pm 0.01$ & $84.9 \pm 2.9$ & $35.0 \pm 1.4$ & $2.6 \pm 0.1$ & $3.3 \pm 0.3$ & $0.64 \pm 0.06$ \\
\hline $150: 60: 120$ & $52.6 \pm 0.8$ & $23.3 \pm 0.8$ & $1.6 \pm 0.0$ & $1.5 \pm 0.3$ & $0.42 \pm 0.01$ & $86.7 \pm 0.3$ & $38.8 \pm 2.7$ & $2.7 \pm 0.1$ & $3.8 \pm 0.1$ & $0.76 \pm 0.04$ \\
\hline
\end{tabular}

Mean \pm S.E.

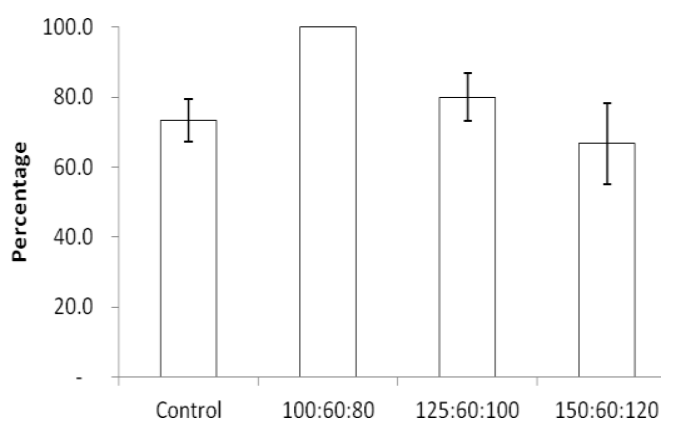

Fig 2. Percentage of $A$. muelleri plants produced two leaves from different NPK $\left(\mathrm{kg} \mathrm{ha}^{-1}\right)$ intercrop with coffee trees in Bogor, West Java, Indonesia. Bar \pm S.E. 
by about 1 to 2 weeks, compared with control. Thus, high NPK application increased length of vegetative period.

Table 4 shows that more than $90 \%$ of corms in control plants weighed less than $300 \mathrm{~g}$. On the other hand, NPK application decreased the percentage corm less than $300 \mathrm{~g}$; by $42.9,63.2$ and $41.7 \%$ at $100: 60: 80$ $\mathrm{kg} \mathrm{ha}{ }^{-1}, 125: 60: 100 \mathrm{~kg} \mathrm{ha}^{-1}$ and 150:60:120 kg ha ${ }^{-1}$ treatments, respectively. According Sugiyama and Santosa (2008), 400 to $600 \mathrm{~g}$ in weight of two-years-old corms are common. Budiman and Arisoesilaningsih (2012) stated that seed corm age determines the yield of $A$. muelleri; and marketable size, i.e., larger than $1 \mathrm{~kg}$ is obtained from seed corm aged 2 or 3-years-old. Thus, the low marketable size in the present experiment is due to younger seed corms than 2-yearsold.

Considering the initial planting corm, average bulking rated of control, 100:60:80 $\mathrm{kg} \mathrm{ha}^{-1}, 125: 60: 100$ $\mathrm{kg} \mathrm{ha}^{-1}$ and 150:60:120 $\mathrm{kg} \mathrm{ha}^{-1}$ NPK treatments were 7.9, 12.9, 8.8, and 9.3 times, respectively. This finding implies that bulking rate of corms increase by NPK application. This study suggested that 100:60:80 $\mathrm{kg} \mathrm{ha}^{-1}$ NPK was recommended, judging from the yield, corm size uniformity and avoidance of leaf discoloration. The leaf discoloration is likely caused by combination of sunburn and physiological problems. However, the detrimental effect of high dosage of NPK has never been reported.

In accordance to this study, the importance of NPK for Amorphophallus growth has been recognized. Nair et al. (1990) reported that Amorphophallus required NPK at the rate of 100:50:150 kg ha-1. John (2008) reported that annually, $A$. paeoniifolius plant extracts $26.9 \mathrm{~g} \mathrm{~N} \mathrm{~m}^{-2}, 4.2 \mathrm{~g} \mathrm{P}_{2} \mathrm{O}_{5} \mathrm{~m}^{-2}$ and $36.6 \mathrm{~g} \mathrm{~K}_{2} \mathrm{O} \mathrm{m}^{-2}$ field, corresponding to 269,42 and $366 \mathrm{~kg} \mathrm{ha}^{-1}$ of $\mathrm{N}$, $\mathrm{P}_{2} \mathrm{O}_{5}$ and $\mathrm{K}_{2} \mathrm{O}$, respectively.

Table 2. Corms size and corm dry matter content of $A$. muelleri treated with different NPK composition grown under intercropping with coffee tree in Bogor

\begin{tabular}{lcccc}
\hline \multirow{2}{*}{ NPK combination } & \multicolumn{3}{c}{ Corm size } & \multicolumn{2}{c}{$\begin{array}{c}\text { Dry matter content } \\
\text { (\%) }\end{array}$} \\
\cline { 2 - 4 } & Fresh weight $\mathbf{( g )}$ & Diameter $(\mathbf{c m})$ & Height $(\mathbf{c m})$ & $15.3 \pm 0.1$ \\
\hline No NPK & $390.0 \pm 56.2$ & $9.6 \pm 0.5$ & $6.0 \pm 0.3$ & $16.9 \pm 0.1$ \\
100:60:80 & $636.3 \pm 91.7$ & $11.0 \pm 0.2$ & $6.5 \pm 0.3$ & $16.5 \pm 0.2$ \\
125:60:100 & $433.3 \pm 107.1$ & $9.6 \pm 0.8$ & $5.8 \pm 0.5$ & $16.7 \pm 0.5$ \\
150:60:120 & $457.7 \pm 65.0$ & $10.0 \pm 0.6$ & $5.9 \pm 0.2$ & \\
\hline
\end{tabular}

Mean \pm S.E.

Table 3. Percentage of healthy corms, average time to harvest, minimum and maximum weight of harvested corms of $A$. muelleri treated with different NPK composition grown under intercropping with coffee tree in Bogor, West Java, Indonesia

\begin{tabular}{|c|c|c|c|c|}
\hline \multirow{2}{*}{ NPK combination } & \multirow{2}{*}{ Healthy corm (\%) ${ }^{z}$} & \multirow{2}{*}{ Time to harvest (WAE) ${ }^{Y}$} & \multicolumn{2}{|c|}{ Corm weight (g) } \\
\hline & & & Min & Max \\
\hline No NPK & 81.33 & $22.9 \pm 0.3$ & 20 & 460 \\
\hline 100:60:80 & 81.33 & $23.6 \pm 0.2$ & 40 & 765 \\
\hline 125:60:100 & 77.33 & $23.7 \pm 0.2$ & 40 & 620 \\
\hline 150:60:120 & 90.67 & $24.6 \pm 0.2$ & 50 & 1100 \\
\hline
\end{tabular}

Table 4. Percentage of weight of harvested A. muelleri corms treated with different NPK composition grown under intercropping with coffee tree

\begin{tabular}{|c|c|c|c|c|c|c|c|}
\hline \multirow{2}{*}{$\begin{array}{c}\text { NPK } \\
\text { combination }\end{array}$} & \multicolumn{7}{|c|}{ 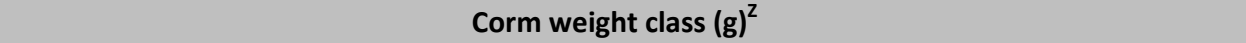 } \\
\hline & $<50$ & $51-100$ & $101-200$ & $201-300$ & $301-400$ & $401-500$ & $>500$ \\
\hline & & & & $\ldots \ldots \% \ldots . .$. & & & \\
\hline No NPK & 3.42 & 19.5 & 53.17 & 20.17 & 2.08 & 1.67 & 0 \\
\hline $100: 60: 80$ & 1.75 & 8.45 & 23.98 & 18.82 & 16.25 & 16.77 & 13.98 \\
\hline $125: 60: 100$ & 10.29 & 10.02 & 28.11 & 12.81 & 15.92 & 11.72 & 6.98 \\
\hline $150: 60: 120$ & 1.59 & 9.99 & 20.79 & 19.31 & 17.90 & 15.64 & 14.78 \\
\hline
\end{tabular}




\section{Second Experiment}

Leaf size and plant growth. There was no significant different on maximum leaf size of $A$. muelleri from different NPK application methods (Table 5). Final plant height was attained at 21 WAP ranged from 55.4 to $69.8 \mathrm{~cm}$, with petioles diameter 2.3 to $2.4 \mathrm{~cm}$, rachis width 40.3 to 58.4 and canopy width 73.3 to $77.5 \mathrm{~cm}$. The final canopy size in this experiment, irrespective of NPK application methods was similar to Exp. 1, but it was smaller than that reported by Sugiyama and Santosa (2008), i.e., 100 to $125 \mathrm{~cm}$. Plants grew under artificial shading net as reported by Sugiyama and Santosa (2008) may receive more uniform sunshine than in the present experiments resulted in larger canopy size.

No significant different was found among method of NPK applications and control plants without supplemented NPK fertilizers (Table 5). Sumarwoto (2005) recommended applying organic manure at rate $1-7$ ton ha ${ }^{-1}$. It is likely that application of manure at rate 5 ton ha ${ }^{-1}$ in the present experiment may adequate for $A$. muelleri growing in intercropping with coffee tree.

Plant grew longer in NPK treated than control ones (Fig.3). About 30\% of control plant entered dormancy at 23 WAP while NPK treated plants started dormant at 25 WAP or two weeks later. All control plants completely dormant at 30 WAP, while NPK treated plant at 33 to 34 WAP. However, there was no significant different on duration of growing time between plants treated with NPK applied by conventional and liquefied methods.
Corm production. Number of aerial bulbils per plant was significantly affected by method of NPK applications, while average corm weight and corm yields were not affected by method of applications (Table 6). Table 6 shows that conventional NPK application to $A$. muelleri plants tended to promote more bulbils production than other treatments. Average fresh corm weight from conventional method of NPK application was slightly higher than that of liquefied ones, but statistically was not different.

More than $47 \%$ plants produced corm seized $<200 \mathrm{~g}$, irrespective of method of application. Conventional application method of NPK or broadcasting beside petiole, promoted plants to produce larger percentage of corm weight in $A$. muelleri larger than $600 \mathrm{~g}$ than liquefied $(32.86 \%$ vs. 11.43\%) (Table 7). The lower percentage of corms seized larger than $600 \mathrm{~g}$ in liquefied probably related to the high incident of diseases infection. In control plant without any NPK application, about $5 \%$ of corm was infected by diseases. Percentage of infected corms from plants treated with liquefied NPK fertilizers was higher than those from conventional ones, i.e., $10 \%$ and $5 \%$, respectively. Nevertheless, it is still unclear the high corm infected by diseases in plants treated with liquefied fertilizer.

Skin of infected corms showed swollen with light brown in color (Fig. 1C) that can be distinguished from healthy ones (Fig. 1B). We have checked the infected corms to pathologist in Department of Plant Protection, Bogor Agricultural University, and it was identified as caused by unknown nematodes and bacteria.

Table 5. Plant height, petiole diameter, rachis and canopy width of $A$. muelleri from different NPK application methods measured at 21 weeks after planting (WAP)

\begin{tabular}{|c|c|c|c|c|}
\hline Treatment & Plant height $(\mathrm{cm})$ & Petiole diameter $(\mathrm{cm})$ & $\begin{array}{l}\text { Rachis width } \\
\text { (cm) }\end{array}$ & $\begin{array}{c}\text { Canopy width } \\
\text { (cm) }\end{array}$ \\
\hline Control (no fertilizer) & $69.8 a$ & $2.3 a$ & $40.3 a$ & $77.5 a$ \\
\hline Liquefied & $63.1 a$ & $2.4 a$ & $45.4 a$ & $77.5 a$ \\
\hline Conventional & $55.4 a$ & $2.3 a$ & $58.4 a$ & $73.3 a$ \\
\hline
\end{tabular}

Values in a column followed by similar alphabet are not statistically different at DMRT $\alpha 5 \%$.

Table 6. Number of bulbils, corm weight and productivity of $A$. muelleri from different NPK application methods at 23 WAP

\begin{tabular}{lcccc}
\multicolumn{1}{r}{ Treatment } & $\begin{array}{c}\text { Number of bulbil per } \\
\text { plant }\end{array}$ & \multicolumn{2}{c}{ Corm weight (g) } & \multicolumn{2}{c}{$\begin{array}{c}\text { Productivity (ton } \\
\text { ha }\end{array}$} & Fresh & Dry mass & \\
\cline { 3 - 5 } Control (no fertilizer) & $2.8 \mathrm{a}$ & $262.2 \mathrm{a}$ & $39.3 \mathrm{a}$ & $6.6 \mathrm{a}$ \\
Liquefied & $3.4 \mathrm{ab}$ & $396.4 \mathrm{~b}$ & $61.7 \mathrm{~b}$ & $9.9 \mathrm{~b}$ \\
Conventional & $4.5 \mathrm{~b}$ & $413.6 \mathrm{~b}$ & $68.6 \mathrm{~b}$ & $10.3 \mathrm{~b}$ \\
\hline
\end{tabular}

Values in a column followed by similar alphabet are not statistically different at DMRT $\alpha 5 \%$. 
According to Sugiyama \& Santosa (2008), hot and humid weather in Bogor promotes diseases infection in

A. muelleri such as caused by Rhizoctonia solani, Fusarium sp and Sclerotium sp.

Exp. 2 showed that uniformity of corm of $A$. muelleri was affected by NPK application, similar results to Exp. 1 (Table 4). Although average corm weight was not statistically different, $A$. muelleri plants supplemented with NPK fertilizer by conventional application tended to have larger percentage of large sized corms than liquefied ones. It is likely that solid fertilizer provides nutrients by slow release, resulted in longer available for plant growth. As a result, the plants exhibited longer vegetative period (Fig. 3). Nevertheless, high incident of disease infection in the present experiment may detrimental to the effect of method of application.

It is generally accepted that liquefied fertilizer is believed to provide available nutrients for plant faster that solid ones. However, high rainfall during Exp. 2, may promote high nutrient leaching from the root zones. Monthly rainfall in October, November,
December, January and February were $256 \mathrm{~mm}, 458$ $\mathrm{mm}, 345 \mathrm{~mm}, 272 \mathrm{~mm}$ and $544 \mathrm{~mm}$, respectively. Therefore, the application of liquefied NPK is not recommended in the area with high rainfall like in Bogor.

\section{Conclusion}

Application of NPK at rate of 100:60:80 kg ha ${ }^{-1}$ increased productivity of $A$. muelleri in intercropping system supplemented manure with 10 ton $\mathrm{ha}^{-1}$. Application of NPK at rate higher than 100:60:80 $\mathrm{kg} \mathrm{ha}^{-1}$ delayed harvest time and caused wide variation of corm size, but did not increase average corm yield. Methods of fertilizer application did not produce any significant different on plant growth and corm yield, but conventional application of NPK tended to promote plant grew longer and produced larger percentage of large-sized corms. Average fresh corm weight was 413 $\mathrm{g}$ and $396 \mathrm{~g}$ per plant from conventional (broadcast) and liquefied applications, respectively. Experiments imply the important of NPK fertilizers to enhance $A$. muelleri production in intercropping system.

Table 7. Percentage of weight of A. muelleri corms treated with different application methods of NPK at harvest ( 34 WAP)

\begin{tabular}{|c|c|c|c|c|c|c|}
\hline \multirow[t]{2}{*}{ Treatment } & \multicolumn{6}{|c|}{ Corm weight class (g) } \\
\hline & $<200$ & $201-400$ & $401-600$ & $601-800$ & $801-1000$ & $>1000$ \\
\hline & \multicolumn{6}{|c|}{$\ldots \% \ldots$} \\
\hline Control no fertilizer & 53.19 & 32.54 & 11.43 & 2.86 & - & - \\
\hline Liquefied & 46.64 & 19.08 & 22.86 & 10.00 & 1.43 & - \\
\hline Conventional & 47.26 & 7.03 & 12.86 & 12.86 & 14.28 & 5.72 \\
\hline
\end{tabular}

Measured from all plants of each treatment, thus not suitable for statistical analysis

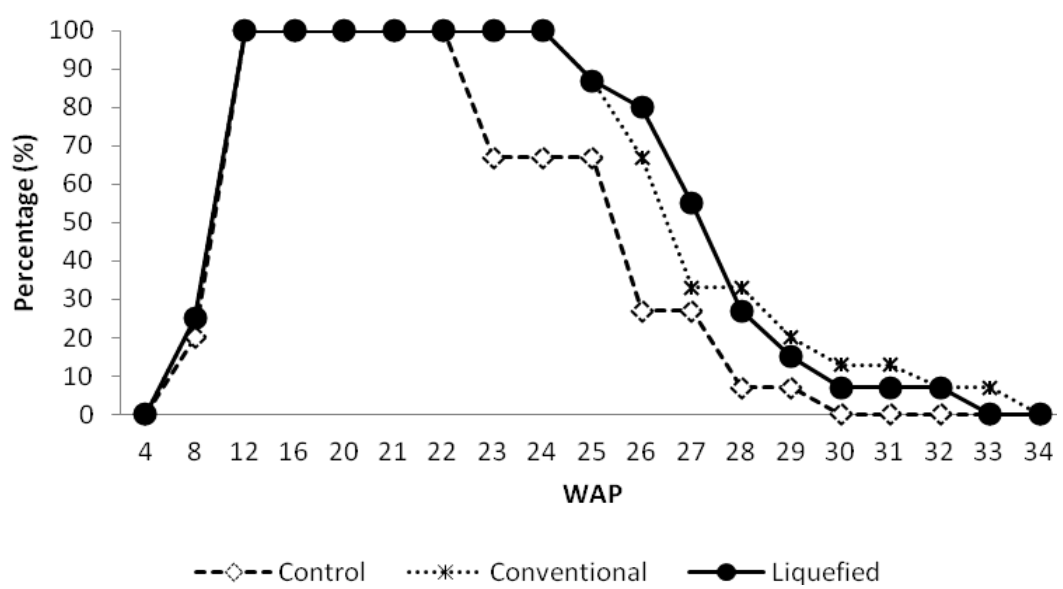

Fig 3. Percentage of growing A. muelleri from different NPK application methods. Values were measured from all plants of each treatment. 


\section{Acknowledgement}

The authors thank Ministry of Research and Technology (Menristek), Republic of Indonesia for financial support through Grant of Applied Research Incentive No RT-2010-0864 and RT-2011-2608. This research was a collaborative research between Bogor Agricultural University, Indonesia and Tokyo University of Agriculture, Japan. Thanks to Ms Lisna Devi Sapitri, and $\mathrm{Mr}$ Haryanto to assist data collection in the field.

\section{References}

Alonso-Sande $M$, Teijeiro-Osorio $D$, Remuñán-López $C$, Alonso MJ. 2009. Glucomannan, a promising polysaccharide for biopharmaceutical purposes. European Journal of Pharmaceutics and Biopharmaceutics. 72:453-462.

Ashokan PK, Nair RV. 1984. Response of taro (Colocasia esculenta (L.) Schott.) to nitrogen and potassium. Journal of root crops. 10:55-57.

Budiman, Arisoesilaningsih E. 2012. Predictive model of Amorphophallus muelleri growth in some agroforestry in East Java by multiple regression analysis. Biodiversitas (13)1:18-22.

Das S, Sen H, Basu A.. 2003. Effect of soil applied nitrogen and potash fertilizers on severity of Phytophthora blight and yield of taro (Colocasia esculenta var antiquorum) under field condition. Indian Journal of Agricultural Science. 73 (12):625-655.

Fang W, Wu P. 2004. Variations of konjac glucomannan (KGM) from Amorphophallus konjac and its refined powder in China. Food Hydrocolloids 18(1): 167-170.

Jansen PMC, Van DWC, Hetterscheid WLA. 1996. Amorphophallus Blume ex. Decaisne. Pp: 45-50. In M. Flach and F. Rumawas (Eds). PROSEA No. 9. Plant Yielding non-seed Carbohydrates. Leiden (NL): Backhuys Publisher.

John SK. 2008. Nutrient dynamics in Amorphophallus: A critical review. Pp: 121-125. In Proceeding National seminar on Amorphophallus : Innovative technologies. India (IN): Indian Council of Agriculture Research, New Delhi.
Liu PY. 2004. Konjac. Beijing (CN): China Agricultural Press.

Nair, PG, Kumar CRM, Saraswathy P. 1990. Effect of different levels of NPK on growth and yield of Amorphophallus under rainfed upland conditions in acid ultisol. Journal of Root Crops. 17:83-86.

Ohtsuki T. 1968. Studies on reserve carbohydrates of four Amorphophallus species, with special reference to mannan. Botanical magazine Tokyo. 81:119-126.

Santosa E, Setiasih I, Mine Y, Sugiyama N. 2011. Nitrogen and Potassium applications on growth of Amorphophallus muelleri Blume. Jurnal Agronomi Indonesia 39 (2): 118-124.

Santosa E, Sugiyama N, Nakata M Lee ON. 2006. Growth and corm production of Amorphophallus at different shading levels in Indonesia. Japanese Journal of Tropical Agriculture. 50 (2): 87-91.

Santosa E, Sugiyama N, Hikosaka S, Kawabata S. 2003. Cultivation of Amorphophallus muelleri Blume in timber forests of East Java, Indonesia. Japanese Journal of Tropical Agriculture. 47(3):190-197.

Sugiyama N, Santosa E. 2008. Edible Amorphophallus in Indonesia-Potential Crops in Agroforestry. Indonesia: Gajah Mada Press, Yogyakarta. 125p.

Sumarwoto. 2005. Pengaruh pemberian kapur dan pupuk kandang terhadap pertumbuhan dan hasil iles-iles (Amorphophallus muelleri Blume). Journal Agroland. 12 (4): 323-329.

Sumarwoto, Widodo W. 2008. Growth and yield of elephant food yam (Amorphophallus muelleri Blume) first growing period of different $\mathrm{N}$ and $\mathrm{K}$. Agrivita 30 (1): 67-74.

Wilson JE, Siemonsma JS. 1996. Colocasia esculenta (L.) Schott. Pp: 69-72. In M. Flach and F. Rumawas (Eds). PROSEA No. 9. Plant Yielding non-seed Carbohydrates. Leiden (NL): Backhuys Publisher.

Zhang D, Wang Q, George SS. 2010. Mechanism of staggered multiple seedling production from Amorphophallus bulbifer and Amorphophallus muelleri and its application to cultivation in South Asia. Tropical Agriculture and Development. 54(3):84-90. 